Hussein Bougsiaa

Matgorzata Cackowska

Lucyna Kopciewicz

Uniwersytet Gdański

\title{
Dzieci w kulturze cyfrowej
}

Intencją naszego tekstu jest próba oglądu zjawiska nowych mobilnych technologii cyfrowych oraz rozważenia ich edukacyjnego i kulturotwórczego potencjału w obszarze problemowym wczesnej edukacji. Mówiąc dokładniej - interesuje nas fenomen urządzeń mobilnych z ekranem dotykowym (smartfony, tablety) w kontekście ich kulturowych, społecznych i edukacyjnych znaczeń.

Problematyka naszego tekstu łączy się z interdyscyplinarnym obszarem badawczym, dotyczącym dziecięcej „socjalizacji digitalnej”: pedagogiką kultury, antropologią cyfrową, socjologią codzienności, socjologią wychowania, pedagogiką mediów i pedagogiką wczesnej edukacji. Przedmiotem naszego szczególnego zainteresowania są kulturowe konstrukcje dzieciństwa w codzienności związanej coraz bardziej z mobilnymi, bezprzewodowymi urządzeniami.

Pojawienie się tych urządzeń owocowało licznymi dyskusjami w obszarze nauk społecznych i humanistycznych na temat zmiany istoty i charakteru społecznych relacji, wzorów kultury, uczenia się i socjalizacji oraz wytworzenia nowych wzorów tożsamości we współczesnym społeczeństwie informacyjnym (Orton-Johnson, Prior 2013). Interesują nas również zmiany dokonujące się w polu rodzinnym jako obszarze międzypokoleniowej komunikacji, dziecięcej socjalizacji i wychowania oraz uczenia się w związku z mobilną rewolucją (Castells et al. 2004). Innymi słowy, próbujemy odpowiedzieć na pytania o bycie m-dzieckiem, czyli o „bezprzewodową" socjalizację i uczenie się (i związane z nimi dyspozycje) oraz „mobilną” rodzinność w digitalnej kulturze w Polsce.

Nasz ogląd wspomnianych zjawisk bardziej jest związany z teoretycznym i metodologicznym podejściem brytyjskich studiów kulturowych, socjologią wychowania oraz pedagogiką wczesnej edukacji (zwłaszcza w obszarze jej zainteresowań kulturową konstrukcją dzieciństwa, kształtowaniem tożsamości dzieci, dziecięcą socjalizacją i emancypacją), socjologią gender (kulturową konstrukcją macierzyństwa oraz przemianami w jego zakresie) niż funkcjonalistycznym spojrzeniem na nowe technologie z perspektywy efektywności i optymalizacji uczenia się dzieci najmłodszych i w młodszym wieku szkolnym. Nie oznacza to jednak, że problem zmiany wzorów uczenia się traktujemy jako nieistotny. Chodzi nam o uczenie się osadzone w kulturze (cyfrowej i mobilnej komunikacji), 
która projektuje jego warunki możliwości, nie zaś o uczenie się jako wyizolowany proces kognitywny.

W niniejszym artykule nawiązujemy do pojęć digital natives i digital immigrants wskazujących na stopień zadomowienia i obcości w kulturze cyfrowej wraz z poznawczymi, kulturowymi i społecznymi konsekwencjami wynikającymi z różnic i nierówności w zakresie tego zadomowienia (Prensky 2001b). Zdajemy sobie sprawę, że pojęcia te wikłają nas w obszar określonych sporów dotyczących problematyki pokoleń i kulturowego statusu nowych technologii komunikacyjnych. Dyskusje te toczą się również wokół pytań o to, czy mamy do czynienia z nową kulturą projektującą odmienną jakość oraz strukturę nauki i socjalizacji, czy raczej mobilne technologie komunikacyjne są jedynie nieco zmienionym (wzbogaconym technologicznie) środowiskiem uczenia się, a ono samo pozostaje niezmienne w swej strukturze (Ally 2009). Naszą intencją nie jest ideologiczne domykanie tych dyskusji i arbitralne potwierdzanie trafności jednej z kulturowych diagnoz dotyczących technologii cyfrowych. Chodzi tylko o wstępny ogląd tego nowego, jeszcze niezbyt dobrze rozpoznanego pola potencjalnych badań empirycznych na styku studiów kulturowych i wczesnej edukacji z odwołaniem do interesującego instrumentarium pojęć, teorii i możliwych ujęć badawczych.

\section{Przedpole teoretyczne i podstawowe założenia}

Pojawienie się mobilnych, bezprzewodowych urządzeń komunikacyjnych (smartfonów i tabletów) jest względnie nowym fenomenem, nieproblematyzowanym jak dotąd na socjo-pedagogicznym gruncie w Polsce. W światowej literaturze przedmiotu odniesienia do rodzinnego kontekstu funkcjonowania urządzeń mobilnych oraz problematyki dziecięcej socjalizacji, zwłaszcza w grupach najmłodszych, też są raczej marginalne. Powodów istnienia takich luk w wiedzy o społeczno-kulturowym kontekście funkcjonowania najmłodszych dzieci w "sferze bezprzewodowej” jest kilka. Pierwszym jest z pewnością „efekt nowości" - urządzenia mobilne pojawiły się stosunkowo niedawno zarówno na świecie, jak i w Polsce. Drugim jest charakter realizowanych badań (polskich i światowych). Choć wiele prac badawczych odnosi się do dzieci - Dzieci Sieci (Siuda, Stunża 2012), Dziecko w świecie mediów elektronicznych (Izdebska 2007) - to dokładniejsza lektura tych prac i raportów badawczych przekonuje, że autorzy odnoszą się do grupy nastolatków (w przedziale wiekowym od dziewiątego do szesnastego roku życia), pomijając grupę dzieci najmłodszych jako aktywnych użytkowników mobilnych urządzeń. Koncentracja badawcza na grupie nastolatków nie może dziwić. Nastolatki najwszechstronniej, najpełniej i najbardziej kreatywnie wykorzystują urządzenia mobilne. To głównie z myślą o nich twórcy i dostawcy nowych technologii komunikacyjnych podejmują starania na rzecz zwiększenia funkcjonalności urządzeń i poszerzenia ich możliwości (dodatkowe funkcje i usługi).

Najliczniejsze analizy poświęcone dzieciom w młodszym wieku szkolnym (i ich rodzicom) są przeprowadzane $\mathrm{w}$ celach marketingowych. Badania wykonane przez agencję Kid Industries (w sondażu uczestniczyło 2200 rodziców dzieci w wieku od trzech do ośmiu lat) w końcu 2011 roku w USA i Wielkiej Brytanii 
wskazują, że 15\% dzieci używa codziennie iPadów swoich rodziców, 9\% posiada swój własny, a $20 \%$ z nich nie ma własnego sprzętu. Aż ponad $77 \%$ rodziców uczestniczących w sondażu jest przekonanych, że używanie tabletu przez dziecko wpływa korzystnie na jego rozwój, pobudzając potencjały twórcze i logiczne myślenie (Pope 2012). Optymizm rodziców względem „cudownych urządzeń" jest wykorzystywany w marketingu, a dziecięca populacja została poważną grupą docelową, do której jest skierowana dynamicznie rozrastająca się oferta aplikacji $^{1}$.

Tymczasem część środowiska psychologów rozwojowych i terapeutów wszczęła panikę moralną w związku ze szkodliwością używania urządzeń z ekranem dotykowym przez małe dzieci. Taki kontakt miał - w opinii psychologów - skutkować problemami rozwojowymi, zaburzeniami koncentracji, nerwowością, wzmagać ADHD oraz prowadzić do autyzmu (Is the iPad bad for children? 2012). Żywym dowodem na szkodliwe oddziaływanie iPada na dzieci stała się czteroletnia Brytyjka: najmłodsze jak dotąd dziecko poddane terapii odwykowej w związku z silnym iPadowym uzależnieniem (Seales, Harding 2013).

Poważny cios psychologicznemu dyskursowi szkodliwości tabletów zadało środowisko rodziców dzieci z autyzmem. Ta grupa przekonuje o „cudownej” mocy tych urządzeń w terapii ich dzieci, w uwalnianiu ich od niektórych skutków autyzmu (Brandon 2011) (wielki postęp w zakresie komunikacji i umiejętności kontrolowania informacji napływających do dziecka ze świata zewnętrznego). Pierwsze aplikacje skierowane do dzieci z autyzmem przeznaczone były na iPada, ale w tej chwili dostępne są już programy na pozostałe urządzenia wyposażone $w$ ekrany dotykowe ( $w$ tym na te $z$ systemem operacyjnym Android). Rodzice i terapeuci potwierdzają, że prostota obsługi, elementy wizualne i intuicyjna natura ekranów dotykowych w połączeniu z przenośnością i atrakcyjnością tabletów oraz iPadów spowodowały przełom $\mathrm{u}$ wielu dzieci z całym spektrum zaburzeń i dysfunkcji. Zdaniem Gary'ego Jamesa, autora strony internetowej z recenzjami aplikacji dla dzieci ze specjalnymi potrzebami edukacyjnymi, tablety przywracają dzieciom głos (w znaczeniu społecznym). Rodzice zwracają uwagę na inkluzywny charakter mobilnych urządzeń, które w niczym nie przypominają stygmatyzujących i rzucających się w oczy pomocniczych materiałów edukacyjnych, z jakich zmuszone są korzystać ich dzieci w kontaktach społecznych. I co najważniejsze, dzięki ekranowi dotykowemu wyeliminowane zostają typowe problemy doskwierające dzieciom $\mathrm{z}$ autyzmem lub niepełnosprawnością ruchową: obsługa klawiatury i zrozumienie związku między myszą i kursorem.

Przeprowadzone przez nas badania sondażowe zatytułowane M(obile) Mama (kwiecień-czerwiec 2013 roku) dostarczyły nam danych empirycznych wskazujących, że polskie dzieci w wieku przedszkolnym i wczesnoszkolnym są aktywnymi użytkownikami mobilnych urządzeń (najmłodszy użytkownik miał dziewięć miesięcy, najstarszy - dziewięć lat), a m(obile) matki dostrzegają w tych urządzeniach prorozwojowy potencjał i niezwykle chętnie włączają mobilne urządzenia w pole socjalizacyjne własnych dzieci. Sfera socjalizacyjnych praktyk odniesionych do tych sprzętów obejmuje zmiany zarówno w sposobach poznawania i organizowania świata przez dziecko (sprawczy dotyk), jak i w układzie relacji

${ }^{1}$ Najbardziej niecodziennym wytworem jest naszym zdaniem iPotty (iNocnik) - nocnik $\mathrm{z}$ wbudowanym ekranem dotykowym (Urist 2013). 
rodzinnych (być może także szkolnych). Okazuje się bowiem, że urządzenia mobilne sprzyjają poznawczej niezależności dziecka. Są też bazą dla jego względnie wyrównanej pozycji w stosunku do osób dorosłych - uniemożliwiają dorosłym sprawowanie pełnej kontroli nad ich aktywnością. Badania M(obile) Mama wskazały istotne - naszym zdaniem - zmiany w sferze praktyk (działania): społeczną nieatrakcyjność komputerów stacjonarnych, frustrację dzieci wywołaną kontaktem z nimi oraz wzrastającą atrakcyjność urządzeń z ekranem dotykowym wynikającą z łatwości ich obsługi. Zgodnie z ustaleniami teoretyków i badaczy społeczeństwa informacyjnego komputer stacjonarny (tradycyjny) staje się symbolem pewnego (minionego) etapu rozwoju tego typu społeczeństwa, a potencjalne oddziaływanie urządzeń mobilnych jest większe niż komputeryzacji tradycyjnej (choćby dlatego, że są dużo popularniejsze w gospodarstwach domowych). Jak twierdzi Manuel Castells, rewolucja informacyjna uzyskała ze strony urządzeń mobilnych nową siłę napędową (Castells 2004). Nie chodzi tu o kwestie bieżących trendów, ale o zasadniczą zmianę środowiska uczenia się i socjalizacji oraz dostępu do kultury cyfrowej (intuicyjna obsługa ekranu dotykowego pociąga za sobą epistemologiczne konsekwencje).

Nasze rozważania dotyczące mobilnych technologii cyfrowych są wyraźnie inspirowane założeniami społecznego konstruktywizmu, odnosząc się do wzajemnych, kulturowych i społecznych, odniesień aktywnego przedmiotu (tablet, smartfon) i człowieka. Staramy się jednak również wykroczyć poza konstruktywistyczne i fenomenologiczne podejście do kultury, które - na gruncie światowych nauk społecznych i humanistycznych - wyraźnie uprzywilejowało pozamaterialne procesy kulturowe (nadawanie lub negocjowanie znaczeń), ignorując sprawcze działanie przedmiotów (Olsen 2010: 562). Innymi słowy, postaramy się zwrócić uwagę na relacyjność przedmiotów (artefaktów) funkcjonujących w sieciach łączących różne rodzaje bytów: ludzi i nie-ludzi (Latour 2010: 526), wskazując na to, że rzeczy także posiadają społeczną sprawczość.

Interesują nas zatem zarówno procesy związane ze sferą praktyk (działania), znaczeń (postrzegania i oceny), jak i pola rodzinnego (jako pola działania sił społecznych) - to na jego terenie dochodzi do kulturowego spotkania dziecka i aktywnego przedmiotu (oraz rodzica udostępniającego dziecku aktywny przedmiot). Zwrócimy również uwagę na potencjalne zderzenie kulturowe szkoły z cyfrową „kulturą mobilną".

\section{Część I. Aktywne przedmioty w polu relacji rodzinnych}

Zadaniem uznanym przez nas za niezwykle istotne jest analiza procesu socjalizacji dzieci (ich inicjacji) w „świat ekranów dotykowych” i mobilnych technologii komunikacyjnych. Czy inicjacja ta dokonuje się spontanicznie, czy jest stymulowana i kontrolowana przez dorosłego pośrednika? W jaki sposób dzieci uczą się poruszać w świecie mobilnych urządzeń? Jakie potrzeby, emocje i przemyślenia towarzyszą im w codziennej praktyce, do której włączają aktywny przedmiot z ekranem dotykowym? W jaki sposób i jak szybko dzieci stają się kompetentnymi użytkownikami takich urządzeń (dotykając na ekranie wszystkiego, co da się dotknąć, metodą prób i błędów, prosząc dorosłego o pomoc czy próbując 
odtworzyć zaobserwowaną sekwencję działań)? Pytania te są istotne w kontekście zainteresowań procesami tworzenia wiedzy przez dzieci.

Jak przekonują Paolo Ferri i Susanna Mantovani, bardzo ważnym, często pomijanym aspektem procesu wkraczania dziecka w świat nowych technologii komunikacyjnych są dorośli pośrednicy (rodzice, nauczyciele). Wspomniani autorzy zwracają uwagę na sferę ich osobistych teorii, przekonań, a często wręcz uprzedzeń do kontaktu dziecka z urządzeniami mobilnymi (Ferri, Mantovani 2006). W teorie te wpisane są przekonania o szkodliwości lub nieszkodliwości tych urządzeń dla zdrowia dziecka, jego rozwoju fizycznego, poznawczego i moralnego, odpowiedniego wieku i poziomu umiejętności dzieci, podatności na uzależnienie od gadżetów, dopuszczalnego czasu używania przedmiotów, stopnia rodzicielskiej/nauczycielskiej kontroli nad dzieckiem, edukacyjnej bądź zabawowej istoty relacji dziecko-przedmiot, wartości nadawanej tej relacji itp. Ferri i Mantovani zwracają uwagę, że dorosły pośrednik (najczęściej rodzic) w sposób zamierzony lub przypadkowy wprowadza dziecko w świat mobilnych technologii komunikacyjnych, obdarzając je kulturowo skonstruowanymi znaczeniami relacji człowiek-przedmiot oraz wyposażając je w pierwsze umiejętności istotne z punktu widzenia szans zadomowienia się w kulturze cyfrowej (Ferri, Mantovani 2006: 6-8). Tym samym autorzy nie są skłonni uznać tezy o pokoleniowym charakterze podziału cyfrowego właściwego dla digital natives i digital immigrants: kontakt z kulturą cyfrową zachodzi bowiem dzięki interwencji dorosłego pośrednika (Ferri, Mantovani 2006: 10).

Problem rodzinnego kontekstu i nowych technologii cyfrowych oraz ich wzajemnych odniesień został podjęty w pracach badawczych Letizii Caronii (Caron, Caronia 2007). Autorka przeciwnie niż Ferri i Mantovani rozpatruje problem socjalizacji cyfrowej szerzej, uwzględniając całokształt codziennych relacji rodzinnych i nie ograniczając się do problematyki dziecięcej nauki. Projekt badawczy Caronii otwierają pytania o znaczenia, jakie nadają mobilnym technologiom komunikacyjnym członkowie badanych rodzin oraz o sensy ich pojawienia się i wykorzystywania w kontekście rodzinnym. Autorka zakłada, że urządzenia mobilne są aktywnymi przedmiotami współtworzącymi materialny kontekst rodzinnej codzienności ze względu na ich umiejscowienie w przestrzeni domowej oraz czas rodzinny związany z ich wykorzystaniem (Caron, Caronia 2001: 39-63). Najistotniejsza jest jednak ich zdolność do wywoływania zmian w układzie rodzinnych relacji.

Obecność urządzeń mobilnych w polu rodzinnym prowadzi do nieoczekiwanych modyfikacji w postaci zmian przyzwyczajeń i nawyków poszczególnych członków rodziny, a niekiedy do poważnej rekonstrukcji w obszarze „prywatnych” norm, wartości i dotychczasowej „rodzinnej kultury”. Badania, w których Caronia posłużyła się wywiadami pogłębionymi i obserwacją codziennego życia włoskich i kanadyjskich rodzin, dowodzą, że zanim mobilne urządzenie pojawi się w polu rodzinnym, zawsze konieczna jest wstępna zgoda członków rodziny na jego włączenie w repertuar wynegocjowanych przyzwyczajeń, norm i wartości: poprzedza ją zatem pytanie o istotność, cel, sens i wartość związaną ze sferą potencjalnych użyć przedmiotu (Caron, Caronia 2001: 42). W kontekście badań Caronii polskie niepokoje o ryzyko uzależnienia się od komputera (i mobilnych gadżetów) można by zatem wyjaśnić przez pryzmat relacji rodzinnych jako pola 
sprzyjającemu powstaniu takiego nałogu. Więc to nie nowoczesna technologia wyzwalałaby (sama z siebie) uzależniającą moc, lecz struktura relacji rodzinnych (wewnątrzrodzinnej komunikacji, przyzwyczajeń, norm i wartości) tworzyłaby układ, w którym aktywny przedmiot staje się dla dziecka jedynym wartościowym partnerem komunikacyjnej wymiany.

Co ciekawe, Caronia, analizując sferę znaczeń i sposobów używania mobilnych urządzeń, nie odnotowała w ogóle problemu nadmiernych form kontaktu z tymi przedmiotami. Udało się jej za to pokazać, jak kultura cyfrowa przeobraża układ relacji rodzinnych poprzez codzienne praktyki komunikacyjne uczestniczących w niej ludzi. Poza oczywistymi użyciami związanymi z pracą zawodową, nauką, poszukiwaniem informacji i rozrywką, badani rodzice dzieci w wieku wczesnoszkolnym - zwłaszcza matki - zwracały uwagę na to, że mobilne urządzenia pozwoliły im na rozwinięcie pełniejszego, bardziej zintensyfikowanego rodzicielstwa (macierzyństwa), które traktują jako komunikacyjnie gęste i często nawiązywane relacje kontroli, opieki, troski, "bycia poinformowaną" o tym, co dzieje się z dzieckiem (Caron, Caronia 2001: 45-51). Dziecko i inni członkowie rodziny stali się - w ich opinii - niemal permanentnie dostępni, co powoduje, że brak łączności (zwłaszcza przedłużający się) jest przyczyną niepokoju, zdenerwowania czy paniki. Zintensyfikowane macierzyństwo i rodzicielstwo realizuje się przez gamę praktyk „pozostawania w ciągłym kontakcie” (SMS, MMS itp.), dających poczucie bycia blisko dziecka oraz poprzez częste rejestrowanie, dokumentowanie i „zatrzymywanie” codzienności (wykonywanie zdjęć i nagrywanie filmów). Dla wielu badanych mobilne urządzenia stały się również okazją do częstszego bycia razem, wspólnego uczenia się, zabawy i odkrywania czegoś nowego. Ta grupa matek zwraca uwagę na wspólnotowy potencjał nowych technologii cyfrowych, które w przeciwieństwie do dawniejszych form (komputer stacjonarny) nie rozwijają w użytkownikach „komunikacyjnego autyzmu”.

W badaniach Caronii ujawnia się jednak wyraźna różnica pokoleniowa w nadawaniu wartości bliskiemu kontaktowi przez poszczególnych członków rodziny. Pokolenie najstarsze (dziadkowie i babcie) uznaje, że prawdziwa komunikacja i emocjonalne „bycie blisko” jako wartości rodzinne mogą być realizowane wyłącznie twarzą w twarz (w bezpośredniej dostępności). Intensywniejsze relacje komunikacyjne za pośrednictwem urządzeń mobilnych są przez nich interpretowane jako nieprawdziwe i mniej wartościowe, podczas gdy w pokoleniu młodszym (rodziców, a zwłaszcza dzieci) wartości rodzinne są integralnie związane z urządzeniami z ekranem dotykowym i nieobecnością podziału na wartościowe i mniej wartościowe formy kontaktu (Caron, Caronia 2001: 58).

\section{Dziecko w świecie aktywnych przedmiotów - badania M(obile) Mama}

W dalszej części tekstu zaprezentujemy niektóre z efektów projektu badawczego zatytułowanego M(obile) Mama. Ogólnym jego celem było pozyskanie wiedzy na temat strategii włączania przez matki urządzeń mobilnych w pole socjalizacyjne własnych dzieci. Badania przeprowadzone w kwietniu i maju 2013 roku zostały wykonane metodą quick study (kwestionariusz on-line) z pięćdziesięcioma 
kobietami w wieku od osiemnastu do czterdziestu lat (matkami dzieci w wieku przedszkolnym i wczesnoszkolnym), mieszkankami dużych i średnich miast w Polsce.

Niemal wszystkie uczestniczki quick study mają wykształcenie wyższe (trzy spośród badanych miały wykształcenie średnie). Reprezentacja zawodowa mobilnych matek przedstawia się następująco: dwanaście nauczycielek, cztery nauczycielki akademickie, cztery wykonawczynie wolnych zawodów, trzy - zawodów artystycznych, trzy prawniczki, cztery wykonujące zawody związane z sektorem bankowym, dwie - związane $\mathrm{z}$ administracją, pięć pracujących na stanowiskach kierowniczych, dwie programistki (ICT), dwie wydawczynie książek, trzy wykonujące zawody usługowe, trzy poszukujące zatrudnienia, trzy uczące się lub studiujące.

Ramy badań empirycznych wyznaczyły nam następujące pytania: jak urządzenia mobilne (smartfon, tablet) są włączane $\mathrm{w}$ przestrzeń rodzinnych relacji i norm komunikacyjnych? Jak współtworzą kulturowe (mobilne) modele rodzicielstwa? Jaki potencjał zmian wnosi aktywny przedmiot (smartfon, tablet) w pole rodzinne i rodzinną komunikację? Jakie znaczenia nadają rodzice mobilnym urządzeniom oraz jak postrzegają i projektują kontakt dziecka z aktywnym przedmiotem? Jak zmieniają się rodzicielskie dyskursy dziecięcego rozwoju, rodzicielskiej władzy i kontroli oraz opieki i nadzoru nad dziećmi w związku $\mathrm{z}$ wprowadzeniem urządzeń mobilnych w pole rodzinne?

Wskazane szczegółowe pytania badawcze wpisują się w ogólniejszą perspektywę rozważań dotyczących tego, w jaki sposób dzieci są wprowadzane w kulturę cyfrową.

\section{Wyniki badań}

Analiza wyników badań wskazuje, że m(obile) matki tworzą grupę, która dopracowała się trzech zróżnicowanych sposobów rozumienia mobilnych technologii, ich funkcji i potencjalnej roli w życiu rodzinnym i życiu ich dzieci:

1. M(obile) matki, które urządzeniom mobilnym nadały status gadżetów i zabawek (dla dorosłych). Grupa ta przejawia silne tendencje kontrolne w stosunku do dzieci korzystających z technologii mobilnych. Ponadto grupa ta rozwija dyskurs uzależnionego dziecka, tym samym stawiając siebie w roli obrończyni „naturalnego środowiska” rozwojowego jako środowiska oczyszczonego ze "szkodliwego wpływu technologii".

2. M(obile) matki, które urządzeniom mobilnym nadały status wspólnotowych narzędzi wspomagających uczenie się i zabawę (o charakterze edukacyjnym). Grupa ta także kontroluje dziecięcą aktywność, niemniej jednak pozytywniej ocenia potencjał prorozwojowości nowoczesnych technologii.

3. M(obile) matki, które urządzeniom mobilnym nadały statusu narzędzi własnej pracy. Ta grupa matek nie posługuje się żadnym dyskursem dziecięcego rozwoju w związku z technologiami cyfrowymi.

Pierwsze $\mathrm{z}$ istotnych zagadnień otwierających sferę znaczeń nadawanych przez badane urządzeniom cyfrowym w relacjach socjalizacyjnych i wychowawczych dotyczyło prawa dzieci do posiadania urządzenia mobilnego (tabletu, 
smartfona) wyłącznie do użytku osobistego. Nie chodziło nam jednak o „efekt marketingowy", czyli ustalenie, czy badane są gotowe na dokonanie zakupu urządzenia dla dziecka, co raczej o ujawnienie ich sposobów rozumienia i oceny samej idei niezależności (autonomii) dziecka jako posiadacza mobilnego urządzenia. Badane w większości nie były entuzjastkami pomysłu dziecięcej autonomii prawa posiadania przez dziecko własnego urządzenia mobilnego. Odpowiedzi matek zawierały spory ładunek ideologicznych konstrukcji odniesionych do szerszych kontekstów - konstrukcji znaczeń komunikacyjnych technologii cyfrowych, sposobu wykorzystania ich przez dzieci oraz funkcji i roli urządzeń z ekranami dotykowymi we współczesnym świecie (w tym w świecie dzieci). Wiele matek wyrażało przekonanie o niekorzystnym (jeśli nie jest kontrolowany) wpływie kultury cyfrowej na rozwój dzieci, dlatego okazały się - w znakomitej większości zwolenniczkami kontroli rozumianej jako rodzicielska władza dawania i odbierania urządzeń mobilnych dzieciom:

Uważam, że do dziesięciu lat dziecko nie powinno mieć własnego sprzętu (b 16) ${ }^{2}$.

Gadżeciarstwo nie w tym wieku! (b 26)

M(obile) matki obawiają się skutków utraty kontroli nad czasem spędzonym przez dziecko z tabletem/smartfonem i stronami internetowymi, aplikacjami, z których korzysta lub które samodzielnie instaluje:

Tablet mojego syna jest pod pełną moją kontrolą i lądują na nim wyłącznie aplikacje, które przetestowałam najpierw sama. Muszą nieść coś dodatkowo poza samą rozrywką. [...] Nie kupujemy dziecku smartfonu/tableta jako bajer, instalujemy pierwsze lepsze aplikacje i dajemy z cichym przekazem „masz, zajmij się sobą i nie zawracaj głowy". Patrząc na to, jak szybko technologie się rozwijają, uważam, że dzieci powinny mieć do nich dostęp, jednak powinien on być „zdrowy” i pod kontrolą rodziców (b 8).

Wolę mieć nad dzieckiem kontrolę (b 14).

Trzeba dawkować i kontrolować (b 41).

Najsilniejszym dyskursem uzasadniającym prawo rodzicielskiej kontroli jest dla matek zdroworozsądkowa wersja psychologii rozwojowej, a w jej ramach kategoria prawidłowego rozwoju dziecka, która umiejscawia wszechstronny, harmonijny, prawidłowy jego rozwój w naturalnym, zróżnicowanym i rzeczywistym środowisku (środowisku off-line):

Dziecko powinno funkcjonować w rzeczywistym świecie, doświadczać go przez wszystkie zmysły, rozwijać umiejętności interpersonalne przez bezpośredni kontakt z innymi dziećmi, rodzicami, ludźmi, uczyć się życia w społeczeństwie, spędzając czas aktywnie (b 29).

Jasiek ma osiem lat. W tym wieku do rozwoju niepotrzebny jest smartfon (b 41).

Oprócz dostarczania rozrywki cyfrowej powinniśmy rozwijać w dzieciach chęć zabawy ruchowej w realu (b 1).

\footnotetext{
${ }^{2}$ Fragmenty wypowiedzi badanych, ilustrujące analizowane zjawiska, zawierają oznaczenia kodowe ankiety.
} 
Wiele wypowiedzi dotyczy również utraty kontroli nad dzieckiem w kontekście ryzyka uzależnienia od gadżetu. W wypowiedziach matek uwidocznia się zarówno proces osobistej (kulturowej) konstrukcji urządzenia jako „zabawki”, „"bajeru”, ,gadżetu”, dziecka - jako istoty podatnej na uzależnienie oraz specyficznej konstrukcji (i dychotomicznego podziału) środowiska rozwoju: naturalnego, korzystnego rozwojowo oraz „sztucznego środowiska” cyfrowej technologii będącej potencjalnym zagrożeniem:

Nie można dziecka od najmłodszych lat uzależniać ${ }^{3}$ czy osaczać technologią (b 4).

Im mniej dziecko korzysta $\mathrm{z}$ aplikacji i gier w smartfonie, tym lepiej dla niego i dla rodziny (b 22).

Wiele m(obile) matek widzi w dziecku irracjonalnego użytkownika mobilnych technologii, który oddałby się im w sposób niekontrolowany i całkowity. Ich oceny dziecięcej aktywności są mocno związane z tym, jak one same zdefiniowały urządzenia mobilne, sens ich posiadania oraz przydatność w codziennym życiu. Kiedy kulturowa konstrukcja urządzenia mobilnego odnosi się wyłącznie do "gadżetu” i „zabawki”, ryzyko narażenia dziecka na kontakt z cyfrowymi technologiami komunikacyjnymi można ująć w następującej formule: cenzura - ochrona przed uzależnieniem - dawkowanie - kontrola - udostępnianie - [cel:] akces do zabawy „mobilną zabawką dla dorosłych”.

Kolejna grupa m(obile) matek traktuje urządzenia mobilne jako narzędzia wspólnotowe (idea wspólnej nauki i zabawy dla dziecka i rodzica), które właściwie wykorzystywane (czyli pod rodzicielską kontrolą) wspomagają rozwój poznawczy dziecka. Trzeba jednak zwrócić uwagę na zmieniającą się koncepcję rodzicielskiej kontroli - tu nie polega ona na odbieraniu urządzenia z dziecięcych rąk po przekroczeniu określonego limitu czasu, ale na towarzyszeniu i czujności podczas wspólnych działań. W tej perspektywie rodzicielska kontrola utrzymuje „niski profil”, jest „wewnętrzną procedurą" wkomponowaną w czas „bycia razem":

Dziecko ma niespełna roczek i korzysta jedynie z jednej aplikacji z obrazkami i dźwiękami zwierzątek. Czasem przeglądamy razem nasze zdjęcia i dzwonimy przez Skype'a do dziadków, gdy jesteśmy w podróży. Czasem oglądamy bajkę. Słuchamy także muzyki podczas zabawy (b 46).

Wskazana grupa matek uważa, że kultura cyfrowa (i mobilne urządzenia) sprzyjają rozwojowi. Nie przeciwstawia go tak wyraźnie środowisku „naturalnemu" i w zdecydowanie większym stopniu niż pierwsza grupa matek akceptuje zmiany w nim zachodzące, dostrzegając w nich potencjał rozwojowy zamiast ładunku destrukcyjnego:

Wszystko się zmienia i nasze dzieci muszą iść z duchem czasu, wykorzystują takie urządzenia do nauki (b 15).

Dzieci bardzo szybko uczą się elektroniki, dzięki czemu rozwijają się lepiej i nie pozostają w tyle jeśli chodzi o rozwój elektroniki (b 25).

\footnotetext{
${ }^{3}$ Wyróżnienia w cytowanych tekstach pochodzą od autorów artykułu.
} 
M(obile) matki należące do drugiej grupy, traktując mobilne urządzenia „wspólnotowo”, wypracowały alternatywną koncepcję rozwoju dziecka: bycie razem - czujność i ochrona - wspólne uczenie się/zabawa w kulturze cyfrowej [cel:] dobre zadomowienie w kulturze cyfrowej.

Ta grupa matek, inaczej niż grupa pierwsza, nie wyklucza możliwości rozwoju dziecka w kulturze cyfrowej. Przeciwnie, rozwój ten jest wpisany w zmieniający się kontekst kulturowy, a proces jego zmiany nie jest traktowany jako zagrożenie:

Moje dwuletnie dziecko umie obsługiwać iPhone'a. Umie zadzwonić do babci, umie ściszyć i pogłośnić, umie przełączyć na system głośnomówiący, umie włączyć muzykę, którą lubi, przegląda filmy, które nakręciliśmy za dnia. Uważam, że to jest rozwijające (b 3).

Badane matki nie uznawały mobilnych urządzeń za zabawki (dla dorosłych) ani gadżety, ale za narzędzia towarzyszące codziennym działaniom: wspierające częstsze kontakty z rodziną, służące dokumentowaniu codzienności, uczeniu się itp. Ten typ znaczeń przypisany przedmiotowi w sferze rodzicielskich praktyk wychowawczych minimalizuje pokusę jego zawłaszczenia przez dziecko jako atrybutu władzy, "dorosłości” lub prestiżu. M(obile) matki konsekwentnie podkreślają wspólnotowość urządzeń, odnosząc się do wypracowywanej - na gruncie zasady wspólnotowości - umiejętności dzielenia się:

Należy uczyć dzieci dzielenia się (b 28).

Trzecia grupa m(obile) matek (najmniej liczna) wykorzystuje tablety i smartfony przede wszystkim jako narzędzia własnej pracy (mobilne biuro, kontakty służbowe, ale też zarządzanie domowym czasem lub finansami). Grupa ta najwyraźniej opowiada się za ideą mobilnej niezależności dzieci. Swoje stanowisko motywuje pragmatycznie - obawą przed utratą (przypadkowym zniszczeniem) urządzenia lub przechowywanych w nim danych (szkody zawodowe), co może nastąpić w przypadku, gdy dziecko bawi się narzędziem pracy matki - oraz ideologicznie (liberalnie) - jako przyznanie dziecku, jak każdej innej istocie ludzkiej, prawa do prywatności, rozrywki i posiadania czegoś na własność:

Aplikacje i pliki to indywidualna sprawa osoby dorosłej i nie chciałabym aby dziecko miało do nich dostęp. Chodzi również o ewentualne zniszczenia w przypadku młodszych dzieci (b 13).

Wychodzę z założenia, że smartfon jest urządzeniem osobistym i każdy powinien mieć swój własny (b 28).

Dziecko - jak każdy człowiek - ma prawo do prywatności, rozrywki. Urządzenia tego typu ma każdy dorosły, więc czemu odmawiać tego dziecku? (b 18)

Wskazana grupa badanych m(obile) matek nie formułuje żadnych warunków wstępnych dotyczących kontaktu dziecka z urządzeniami mobilnymi. Nie posługuje się też żadnym specyficznym "dyskursem rozwojowym" w związku $\mathrm{z}$ kulturą cyfrową. Warto jedynie podkreślić, że badane posługują się kategorią 
dzieciństwa rozumianego indywidualistycznie, przez pryzmat podmiotowych praw, zwłaszcza prawa do prywatności i posiadania własności.

\section{Urządzenia mobilne w dyskursach rozwoju dziecka}

Jak już wskazywaliśmy, wiele m(obile) matek postrzega kulturę cyfrową przez pryzmat dyskursu „niepokoju i troski”, traktując ją albo jako zagrożenie dla rozwoju dziecka, albo jako konieczny i oczywisty element jego społecznego świata. Jednak kontakt z kulturowymi artefaktami, przefiltrowany przez sito rodzicielskiej kontroli (czasu, edukacyjnej wartości aplikacji itp.) nabiera w oczach wielu matek biorących udział w badaniu prorozwojowych wartości. Badane najczęściej odnosiły się do nabywania przez dziecko niezbędnych kompetencji sprawnego sprawnej orientacji w kulturze cyfrowej, odnajdywania i przetwarzania informacji, stymulowania kreatywności, spostrzegawczości oraz sprawności manualnej.

Do pozytywnych stron partycypacji dziecka w kulturze cyfrowej badane zaliczyły:

Rozwój pewnej niezbędnej we współczesnym świecie inteligencji poruszania się po scyfryzowanym otoczeniu, wyobraźni, a nawet kreatywności (b 1).

Wartościowe aplikacje rozwijają jego spostrzegawczość, uwrażliwiają, dają poczucie sprawstwa, dają możliwość odkrywania i spontanicznej nieschematycznej aktywności (b 31).

Dzięki temu dziecko ma możliwość szybszej nauki poprzez zabawę (b 48).

Poszerzenie wiadomości, sprawne posługiwanie się sprzętem elektronicznym (b 37).

Jest „na bieżąco” z techniką, potrafi w sposób szybki i konkretny znaleźć potrzebne informacje (b 12).

Uczy się alfabetu, liczenia, kolorów, kształtów, rozwija zdolności, kreatywność, zdolności manualne, pamięć, spostrzegawczość, uczy języków obcych podczas zabawy korzystając z aplikacji mobilnych dla dzieci, uczy innych obsługi sprzętów (b 8).

Badane podkreśliły, że szybkie zadomowienie dziecka w kulturze cyfrowej daje mu mocniejszą (bardziej zrównoważoną) pozycję w kontaktach $\mathrm{z}$ mniej kompetentnymi dorosłymi i staje się nauczycielem, przewodnikiem po świecie, w którym sami poruszają się mniej sprawnie:

Moje dziecko staje się kompetentnym użytkownikiem, radzi sobie z urządzeniami, uczy obsługi własną babcię (b 23).

Badane zwróciły uwagę na własne korzyści osiągane w związku z korzystaniem przez dziecko z urządzeń mobilnych (na przykład przerwanie nudy lub monotonii podróży, opanowanie dziecięcego płaczu, chwila wytchnienia itp.):

Dziecko nie nudzi się podczas podróży (b 22).

Dla mnie chwila wolnego, dla dziecka zabawa - nauka i nieodstawanie od innych dzieci (b 2). 
Wytchnienie dla rodziców... (b 40)

Można go na chwilę zainteresować smartfonem, światełkiem, dźwiękiem itp., gdy jest kryzysowa sytuacja, na przykład płacz w samochodzie (b 11).

Inna z kwestii podkreślanych przez m(obile) matki odnosi się do oczywistej funkcji urządzeń mobilnych - komunikacji. Wbrew obiegowym przekonaniom o tym, że wczesna styczność dzieci z kulturą cyfrową zamyka je na relacje międzyludzkie i ogranicza swobodną komunikację rówieśnicząa , badane m(obile) matki podkreślają raczej intensyfikację kontaktów społecznych, zwłaszcza rodzinnych, które umożliwia technologia mobilna. Warto również odnotować, że urządzenia mobilne przy okazji skutecznie pełnią funkcję narzędzi rodzinnej kontroli:

Jeżeli potrzebujemy jakiejś informacji szybko, to technologia mobilna pomaga: mamy kontakt z dzieckiem cały czas (b 15).

Dziecko jest w kontakcie z innymi lub rodzicami (b 21).

Szybkie przekazywanie informacji mamie, częste pisanie smsów (werbalizowanie swoich myśli). Rozwijanie relacji z rówieśnikami (b 26).

Możliwość częstego kontaktu z dziadkami (b 28).

Bezpieczeństwo! Zawsze może się skontaktować z kimś dorosłym, a i z dzieckiem jest ułatwiony kontakt (b 38).

Jak się okazuje, mobilne urządzenia przynoszą obopólne korzyści: dzieci rozwijają się w sieci komunikacyjnych kontaktów społecznych, matki zaś mają sposobność sprawowania pełniejszego, bardziej zintensyfikowanego macierzyństwa. Dla badanych owo pełniejsze macierzyństwo oznacza komunikacyjnie gęste i często nawiązywane relacje kontroli, opieki, troski, "bycia poinformowaną" o tym, co dzieje się z dzieckiem. Z wypowiedzi badanych matek wynika, że sieć relacji rodzinnych zagęszcza się komunikacyjnie: dziecko i inni członkowie rodziny są niemal permanentnie dostępni. Inną właściwością pełniejszego macierzyństwa są praktyki dokumentowania codzienności (wykonywane filmy lub zdjęcia) oraz praktyki „bycia w kontakcie” (wysyłanie SMS-ów, MMS-ów) dających poczucie bycia blisko siebie w komunikacyjnej przestrzeni (Caron, Caronia 2007).

\section{Ekran dotykowy - rozwojowy rachunek zysków i start}

Ponad połowa badanych m(obile) matek dostrzega zmiany, które dokonały się pod wpływem kontaktu z urządzeniami mobilnymi. Z tego zaledwie pięć badanych wskazuje na negatywny charakter tych zmian. Do zachowań dziecięcych wzbudzających szczególną dezaprobatę matek należą: uzależnienie od dotykania ekranu urządzenia, płacz, gdy dziecko nie może go dostać, nadmierne pochłonięcie dziecka przebiegiem gry, nerwowość i pobudzenie dziecka wynikające z używania tego typu sprzętu:

\footnotetext{
${ }^{4}$ Obraz „otępiałego" dziecka, wpatrzonego w komputerowy ekran, niepodejmującego żadnych aktywności, niemającego żadnych zainteresowań poza światem wirtualnym, nieczującego potrzeby kontaktów z rodzicami i rówieśnikami.
} 
Jedno z dzieci ma problem z kończeniem zabawy - budzi to jego złość (b 5).

Niestety tak: obsesyjne myślenie o tym, co się w grze teraz dzieje, kto gra, co się zmieniło. Brak skupienia, niechęć do wykonywania żmudnych zadań (b 33).

Synek koleżanki uzależnił się od dotyku telefonu Apple. Niby śmieszne, ale koleżance nie jest do śmiechu (b 34).

Zmiany negatywne! Większość analfabetów! (b 15)

Pozostałe badane matki wskazują na pozytywne zmiany przypisywane styczności dzieci z mobilnymi technologiami. Zaliczają do nich: naturalny, niebudzący strachu kontakt z urządzeniami komunikacyjnymi, szybszą w porównaniu z rówieśnikami znajomość kolorów, kształtów, cyfr i liter przez najmłodsze dzieci, umiejętność samodzielnego nagrywania filmów oraz konstruowanie na ich podstawie krótkich opowiadań, sprawniejszą naukę języków obcych, zainteresowanie czytaniem, zdobywanie wiedzy ogólnej oraz nabieranie pewności siebie. Zmiany te ilustrują następujące wypowiedzi badanych:

Hania nauczyła się już niemal wszystkich liter, poznaje cyfry. Telefon jej w tym pomaga dzięki klawiaturze. Rozwija swoją komunikatywność, więcej stara sie opowiadać. Dzięki temu rozwija słownictwo. Rozwija się też muzycznie, śpiewając piosenki, które mam w swojej muzycznej bibliotece - bardzo lubi słuchać różnorodnej muzyki. Tańczy. Kontakt $\mathrm{z}$ telefonem, nauka obsługi urządzenia utrwala jej pamięć. Filmy, na których Hania ogląda siebie od pierwszego miesiąca życia, poszerzają jej wizję świata (b 2).

Jest bardziej otwarta na świat (b 19).

Wiele aplikacji zainstalowanych na iPadzie, w które grał mój syn, przyczyniło się do szybszej nauki między innymi cyferek, literek, kolorów, kształtów, języków obcych itd. (b 8).

Uczy się wykorzystywać współczesne urządzenia. Nie boi się ich, korzystanie z nich staje się naturalne (b 10).

Więcej i chętniej czyta. Ma sporą wiedzę (b 12).

Myślę, że to zmiana mentalności całego tego pokolenia. Dziecko ma poczucie permanentnego dostępu do informacji. Zawsze, kiedy mamy jakieś wątpliwości, mówi: "to sprawdź w telefonie". Nie ma kłopotu z obsługą różnych urządzeń mobilnych czy elektronicznych (b 24).

Wypowiedź badanej dotycząca zmian pokoleniowych $\mathrm{w}$ traktowaniu informacji jako natychmiastowo dostępnych można przypisać jednemu z wiodących sposobów rozumienia kultury cyfrowej, które zaproponował Marc Prensky (2001a). Opisany przez autora podział pokoleniowy na cyfrowych tubylców i cyfrowych imigrantów, wskazujący na wymiar zadomowienia i obcości w kulturze cyfrowej, pociąga za sobą istotne poznawcze, kulturowe i społeczne konsekwencje. Do najważniejszych należą nowe kulturowe ramy uczenia się i socjalizacji konstytuujące nowe typy tożsamości.

Kolejną ze zmian dostrzeganych w dziecięcym zachowaniu (którą jesteśmy skłonni przypisać dzieciom z pokolenia digital natives) jest traktowanie urządzeń elektronicznych w taki sposób, jak gdyby każde z nich było wyposażone w ekran dotykowy. Tym samym w najmłodszym pokoleniu zaczyna się kształtować 
poczucie oczywistości takiego sposobu obcowania z rzeczywistością i - być może - poznawczego „otwierania” świata przez dotyk, podobnie jak dotyk „ożywia” $\mathrm{i}$ „otwiera” zainstalowane w urządzeniu aplikacje:

Traktuje różne urządzenia na zasadzie ekranu dotykowego (b 44).

Czasem się zdarza, że mój synek dotyka palcem okna i chce pomniejszyć ręką drzewo, które rośnie w ogrodzie (b 50).

Choć badane matki nie odniosły się szerzej do tego problemu, jest on opisywany w literaturze jako zmiana o istotnych konsekwencjach epistemologicznych (Castells 2004). Inny skutek wzrastania dzieci w otoczeniu ekranów dotykowych dotyczy ich sprawności w zakresie obsługi komputerów stacjonarnych. Jak się bowiem okazuje, dzieci dorastające w świecie dotykowych ekranów, które opanowują obsługę nowych urządzeń mobilnych w sposób intuicyjny, szybki i łatwy (zupełnie jakby urządzenia te zostały zaprojektowane z myślą o małych dzieciach) odczuwają spore trudności i frustrację, kiedy mają styczność z tradycyjnymi komputerami stacjonarnymi (problem w obsłudze dużego urządzenia z nieporęczną myszką, nieumiejętność koordynacji ruchów myszy i kursora, traktowanie stałego umiejscowienia komputera i niemobilnego sposobu jego obsługi jako wady). Innymi słowy, komputer stacjonarny staje się dla dzieci urządzeniem trudnym, nudnym i mało atrakcyjnym. W porównaniu $\mathrm{z}$ wygodnymi i lekkimi urządzeniami mobilnymi wydaje się reliktem minionej epoki.

Manuel Castells nazwał pojawienie się nowych technologii rewolucją mobilną, mając na uwadze warunkowane przez nie zmiany kulturowe. Istota Castellowskich rozważań dotyczących mobilnej rewolucji jest teoretycznie bliska ustaleniom Margaret Mead (1978) poświęconym alternatywnym możliwościom przekazu kultury (wiedzy) - układom: kofiguratywnemu (przekazu wiedzy w relacjach rówieśniczych) oraz prefiguratywnemu (przekazu wiedzy przez pokolenie młodsze pokoleniu starszemu). Badania społecznych kontekstów technologii mobilnych dowodzą, że współcześnie największą kulturotwórczą siłą w tym zakresie dysponują dzieci i młodzież. Castells uważa, że mamy do czynienia z istotną zmianą o charterze kulturowym i wskazuje na ścisły związek między rozpowszechnieniem komunikacji mobilnej a tworzeniem się nowej kultury nastolatków wraz ze zmianami w sferze języka, organizacji czasu i przestrzeni. Najpoważniejsza zmiana kulturowa wiążąca się z rewolucją mobilną dotyczy jednak modelu uczenia się. Choć w dalszym ciągu mamy do czynienia z wertykalnym modelem przekazu wiedzy, to odwróceniu ulega kierunek jej przepływu od pokoleń młodszych do starszych (Castells 2004).

\section{Ekran i rodzicielskie procedury kontroli}

Kolejny wątek naszych badań dotyczy problemu rodzinnych zasad pojawiających się w związku z korzystaniem przez dziecko z mobilnych urządzeń (problem władzy dorosłych nad dzieckiem jako użytkownikiem technologii mobilnych). W zgromadzonym materiale empirycznym motyw kontroli nad dzieckiem zaistniał jako jeden z najistotniejszych problemów podkreślanych przez m(obile) 
matki. Tym razem uwidocznił się w perspektywie pytań o zbiór zasad, które są komunikowane dziecku w związku z wykorzystywaniem przez nie urządzeń mobilnych. W materiale empirycznym brak odniesień do stopnia negocjowalności tych zasad (i udziału dzieci w ich ustanawianiu). Przypuszczamy, że są one najprawdopodobniej narzucone siłą rodzicielskiego autorytetu i raczej nie podlegają dyskusji.

Niemal wszystkie badane matki, odnosząc się do zbioru zasad regulujących dziecięce korzystanie z urządzeń mobilnych, dokonały podziału czasu: na „czas cyfrowy" - ściśle kontrolowany i „czas analogowy” - niezwiązany z kontrolą:

Ograniczyłam czas spędzony przed urządzeniem do dwudziestu minut dziennie, ze względu na wiek dziecka (b 1).

Dziecko korzysta z urządzenia mobilnego tylko w weekendy, przez ograniczony czas i tylko z wybranych aplikacji (b 24).

Ustaliłam limit czasowy na dzień (b 44).

Pewna część badanych matek wprowadziła dodatkowo zakaz samodzielnego instalowania aplikacji, używania urządzeń bez pozwolenia osoby dorosłej i korzystania z niego przed odrobieniem lekcji. Przez zakazy przemawia troska matek o umiejscowienie urządzeń mobilnych we właściwych ramach (edukacyjnych, moralnych, kulturowych) oraz o respektowanie przez dziecko relacji władzy - dziecko ma być posłuszne regułom ustanawianym przez dorosłych:

Dziecko może korzystać z tabletu maksymalnie dwadzieścia minut dziennie, ustaliliśmy z jakich stron może korzystać, sprawdzam, czy dziecko przestrzega ustalonych zasad (b 15).

Jeśli korzysta, to w czasie przeznaczonym na rozrywkę. Przed zainstalowaniem nowych aplikacji dziecko pyta o zgodę (b 13).

Ja sama decyduję, czy to dobry moment do zabawy, ale na prośbę dziecka (b 32).

Czas na "głupoty" ograniczony do jednej godziny. Po tym czasie każda kolejna godzina skutkuje obniżeniem kieszonkowego dziecka (b 35).

Zakaz użycia bez mojego pozwolenia (b 30).

Niektóre z tych reguł są wyrażone niezwykle autorytarnie i nie pozostawiają żadnej przestrzeni do negocjacji:

Zasada jest jedna: nie korzysta! (b 26)

Kilka matek (tych, dla których urządzenia mobilne mają wartość wspólnotową) wskazało na ustanowienie reguł związanych z dyrektywą wzajemności, na przykład dbanie o przestrzeganie kolejności, o niezawłaszczanie urządzenia, o dzielenie się nim:

Obowiązuje zasada: „raz ty, raz ja” (b 17).

Uzasadniając sensowność istnienia rodzinnych zasad regulujących korzystanie dziecka ze sprzętu, m(obile) matki odnoszą się głównie do: 
a) obaw przed szkodami rozwojowymi (i uzależnieniem dziecka od smartfona lub tabletu):

Nie chciałam uzależnić dziecka od korzystania z urządzenia oraz znieczulić na innego rodzaju zabawy i zajęcia (b 1).

Bez tych zasad urządzenia te byłyby zagrożeniem, a nie szansą rozwoju (b 5).

b) obaw przed utratą kontroli nad dzieckiem i jego codzienną aktywnością:

Ponieważ dziecko ma również obowiązki. Instalowanie oprogramowania bez mojej zgody spowoduje brak kontroli nad tym co robi dziecko (b 13).

c) obaw przed zawłaszczeniem sprzętu przez dziecko:

Ponieważ syn zaczął „zawłaszczać” iPada, który jest moją zabawką! (b 12)

Aby zapobiec kłótniom o sprzęt (b 17).

d) strachu przed zniszczeniem urządzenia:

Aby czuć się bezpieczniej, że nie stracę sprzętu, bo zleci po schodach przez nieuwagę dziecka (b 8).

M(obile) matki odnoszą się do pewnej filozofii wychowania (lansowanej w mediach), zgodnie z którą dziecko czuje się bezpiecznie w świecie uporządkowanym przez narzucone i jasno określone zasady:

W każdej sferze życia codziennego mojego syna obowiązują go z góry ustalone zasady, zatem i na tej płaszczyźnie są one konieczne. Przestrzegania zasad gwarantuje ład, harmonię, zaufanie i poczucie bezpieczeństwa (b 27).

M(obile) matki wskazały także, z jakiego typu aplikacji najczęściej korzystają ich dzieci. Prezentujemy je w porządku od największej do najmniejszej liczby wskazań: gry dla dzieci (22), aplikacje edukacyjne (8), You Tube (8), aplikacje graficzne (7), kamera i aparat fotograficzny (7), bajki (4), Skype (4), interaktywne książki (3), odtwarzacz muzyki (3).

Powody, dla których badane cenią te aplikacje, przedstawiają się następująco: wygoda, łatwość obsługi urządzenia lub aplikacji (9), łatwość i szybkość komunikacji (pozostawania w kontakcie z ludźmi) (8), natychmiastowy dostęp do informacji (8), ułatwienie, usprawnienie codziennego życia (prywatnego, zawodowego) (8), śledzenie rozwoju dzieci (dokumentowanie, nagrywanie) (4).

$\mathrm{Z}$ wypowiedzi badanych wynika zatem niezbicie, że powodem ich pozytywnych ocen jest dostrzeganie korzyści wnoszonych przez urządzenia (aplikacje) do codziennego życia (ułatwienie, usprawnienie) w aspekcie czasu (szybki dostęp do informacji) oraz $\mathrm{w}$ aspekcie relacji i komunikacji związanej $\mathrm{z}$ organizacją codzienności.

Badane odniosły się także do aplikacji, które uważają za zbędne i ich nie cenią. Należą do nich: gry (13), Facebook (3), sklepy internetowe (3), pogoda (1), mp3 (1), reklamy (1), nie ceni tego, z czego nie korzysta (14). 
M(obile) matki są zdania, że aplikacje te zabierają czas, są niepotrzebne i nieprzydatne, są ogłupiające lub denerwujące. Wątek ten nie jest jednak zbytnio pogłębiony przez badane i znajduje skromną ilustrację w postaci pojedynczych, zazwyczaj lakonicznych ocen i wypowiedzi.

Konkluzja zrelacjonowanych przez nas badań mieści się, naszym zdaniem, w następującej formule: badane m(obile) matki jako użytkowniczki aktywnych przedmiotów chętnie korzystają z dobrodziejstw, ułatwień i usprawnień, które im samym oferuje mobilna technologia. Jednak $z$ dużą ostrożnością i pewną dozą uprzedzeń odnoszą się do własnych dzieci jako użytkowników tych przedmiotów.

\section{Część II. Szkoła, komputer i gadżety? Problem władzy i kontroli}

Polska szkoła mierzy się z zadaniem oswojenia nowych technologii komunikacyjnych, obierając za punkt wyjścia iluzję pierwszego kontaktu dziecka z komputerem na szkolnym terenie. Lektura nowej podstawy programowej dla pierwszego etapu edukacyjnego nie pozostawia wątpliwości, że szkoła przygotowuje dzieci do styczności z komputerami stacjonarnymi, ale pomija urządzenia mobilne właściwe obecnej fazie rozwoju społeczeństwa informacyjnego. Jest to z pewnością podyktowane kondycją finansową polskiej szkoły, ale również nie bez znaczenia pozostaje jej tradycyjne „opóźnienie” względem współczesności. Nowa podstawa programowa dla pierwszego etapu edukacyjnego zawiera następujące stwierdzenia: uczeń, który kończy klasę pierwszą (zajęcia komputerowe),

posługuje się komputerem w podstawowym zakresie: uruchamia program korzystając z myszy i klawiatury. Wie jak trzeba korzystać z komputera, żeby nie narażać własnego zdrowia. Stosuje się do ograniczeń dotyczących korzystania z komputera (Rozporządzenie MEN) $^{5}$.

\section{Natomiast uczeń kończący klasę trzecią}

umie obsługiwać komputer: posługuje się myszą i klawiaturą; poprawnie nazywa główne elementy zestawu komputerowego; posługuje się wybranymi programami i grami edukacyjnymi, rozwijając swoje zainteresowania, korzysta z opcji w programach; wyszukuje i korzysta z informacji: przegląda wybrane przez nauczyciela strony internetowe (np. stronę swojej szkoły), dostrzega elementy aktywne na stronie internetowej, nawiguje po stronach w określonym zakresie, odtwarza animacje i prezentacje multimedialne; tworzy teksty i rysunki: wpisuje za pomocą klawiatury litery, cyfry $\mathrm{i}$ inne znaki, wyrazy i zdania, wykonuje rysunki za pomocą wybranego edytora grafiki, np. z gotowych figur; zna zagrożenia wynikające z korzystania z komputera, Internetu i multimediów: wie, że praca przy komputerze męczy wzrok, nadweręża kręgosłup, ogranicza kontakty społeczne; ma świadomość niebezpieczeństw wynikających z anonimowości kontaktów i podawania swojego adresu; stosuje się do ograniczeń dotyczących korzystania z komputera, Internetu i multimediów (Rozporządzenie MEN).

${ }^{5}$ Rozporządzenie Ministra Edukacji Narodowej z dnia 23 grudnia 2008 r. w sprawie podstawy programowej wychowania przedszkolnego oraz kształcenia ogólnego $\mathrm{w}$ poszczególnych typach szkół (Dz. U. z 2009 r. Nr 4, poz. 17). 
Lektura podstawy programowej przekonuje o wysiłku szkoły skierowanym na stopniowe dopuszczenie uczniowskiej populacji do partycypacji w kulturze cyfrowej (pierwsza klasa pozostaje konsekwentnie poza Internetem). Niemniej jednak zwracają uwagę projektowane nauczycielskie strategie nadzorcze i kontrolne dotyczące kolejnych etapów i „dopuszczeń" (na przykład odwiedzanych stron internetowych pod ścisłą kontrolą nauczyciela). Kontakt z kulturą cyfrową w szkolnych ramach bazuje na ograniczeniach i kontroli, stąd można przypuszczać, że rewolucja mobilna będzie dla szkoły doświadczeniem porównywalnym z "szokiem kulturowym” (ze względu na natychmiastowy dostęp do Internetu i niemożność zachowania pełnej kontroli nad aktywnością użytkowników).

Warto również zwrócić uwagę na inne anachronizmy. Dzieci w wieku wczesnoszkolnym wywodzące się ze środowisk o przeciętnym kapitale kulturowym inicjację w świat nowych technologii mają już za sobą, a wczesnoszkolny instruktaż $\mathrm{w}$ zakresie obsługi komputera stacjonarnego nie wywołuje emocji porównywalnych $\mathrm{z}$ tymi doświadczanymi $\mathrm{w}$ kontakcie z najnowszymi urządzeniami mobilnymi (smatfony, tablety). Jesteśmy rzecz jasna świadomi ideologicznej pracy korporacji, sił rynkowych i skutecznego marketingu działających na populację najmłodszych konsumentów, której efektem są dziecięce pragnienia kierowane w stronę mobilnych gadżetów. Jednak warto zwrócić również uwagę na ideologiczną pracę szkoły (nie tylko polskiej) dokonującej wyraźnego podziału w obszarze narzędzi komunikacyjnych. Traktuje komputery stacjonarne jako dobre, prawomocne i edukacyjnie istotne narzędzia, natomiast zakazuje lub poważnie ogranicza możliwość używania telefonów komórkowych, smartfonów, wnoszenia na teren szkoły tabletów. Urządzenia mobilne uznawane są za modne, rozpraszające, bezużyteczne i służące pustej rozrywce gadżety, a ich posiadanie jest przejawem konsumenckiego zniewolenia i próżności.

Chcąc uchwycić ideologiczną pracę szkoły, dokonaliśmy wstępnej analizy ukrytego programu jednego z przykładowych podręczników wykorzystywanych w pierwszej i drugiej klasie szkoły podstawowej (Zajęcia komputerowe ${ }^{6}$ ) oraz przeanalizowaliśmy pięć statutów szkolnych (szkół podstawowych ${ }^{7}$ ) w celu identyfikacji regulacji odnoszących się do mobilnych urządzeń uczniowskich (może również nauczycielskich) na szkolnym terenie. Zdajemy sobie sprawę z ograniczonej możliwości wnioskowania i budowania szerszych uogólnień na podstawie niewielkiej próbki analizowanych tekstów. Są one jedynie punktem wyjścia dla dalszych prac, które podejmiemy w tym zakresie.

Zajęcia komputerowe (Kęska 2012a, 2012b) to podręcznik i ćwiczenia (oraz płyta CD zawierająca gry edukacyjne) o instruktażowym charakterze. Dzieci korzystające $\mathrm{z}$ tego podręcznika zyskują wiedzę o budowie komputera stacjonarnego, składzie podstawowego zestawu komputerowego, poznają nazwy urządzeń wspólpracujących z komputerem, podstawową wiedzę z zakresu jego obsługi (objaśnienie poszczególnych elementów pulpitu) oraz elementarne umiejętności

\footnotetext{
${ }^{6}$ Podręcznik ten był wykorzystywany w przypadku wielu pakietów edukacyjnych wydawnictwa Nowa Era.

${ }^{7}$ Badaniami objęto pięć trójmiejskich szkół podstawowych, które zechciały nam udostępnić Regulaminy (te ich fragmenty, które dotyczą kwestii urządzeń elektronicznych). Identyfikacyjne dane tych szkół zostały utajnione.
} 
obsługi programu Windows i MS Paint. Nie oznacza to jednak, że przekazy zawarte w podręczniku dotyczą wyłącznie umiejętności obsługi komputera. Bardzo ciekawie przedstawiona została sfera społecznych zastosowań nowoczesnych technologii wraz z dyskursem uzasadnień oraz "dyskursem moralnym" programem właściwego korzystania z komputerów (nie są to jednak bardzo rozbudowane działy podręcznika i obszerne treści). Komputer nazwany przez autorów podręcznika konsekwentnie i często "tajemniczą skrzynką" (na przykład Kęska 2012a: 8) pojawia się w sferze zastosowań, ułatwień i usprawnień pracy. Ukazane są miejsca, gdzie korzysta się z komputerów (stanowiska pracy - biurko urzędniczki) lub pracownicy związani z określoną instytucją (listonosz, policjant) wykorzystujący komputer w aktywności zawodowej. Można zatem stwierdzić, że dyskurs użyteczności komputera jest lokalizowany w kontekście „poważnych” aktywności społecznych. Drugą odsłoną jest sfera prywatna, w której komputer jest przedstawiany jako urządzenie pomocne i usprawniające wykonanie wielu codziennych czynności (czytanie, malowanie, odrabianie lekcji). Co ciekawe, autorzy „ocenzurowali” kontekst zabawowych zastosowań komputera (ani na ilustracjach, ani w tekście nie znajdujemy odniesień do zabawy, gry, rozrywki). Taką konstrukcję jesteśmy skłonni interpretować jako próbę związania świata technologicznego ze sferą racjonalnych (poważnych) zastosowań po to, by prawdopodobnie osłabić dziecięcą konstrukcję: komputer $=$ rozrywka.

Bardzo interesującą częścią podręcznika jest rozdział pierwszy zatytułowany W świecie kabli i tajemniczych skrzynek. Autorzy przedstawiają tu bowiem regulamin pracowni komputerowej, czyli zbiór „zasad właściwego korzystania z komputerów". Zasady te nie dotyczą jedynie szkolnej przestrzeni - wiele ilustracji pod tekstem odnosi się do pracy z komputerem w domu (ilustracja wskazuje dziecięcy pokój). Katalog zasad poprzedza krótki tekst, w którym dostrzegamy kilka zastanawiających stwierdzeń: „Widzieliście kiedyś tyle komputerów w jednym miejscu? To pracownia komputerowa. Może ta nietypowa klasa nieco was onieśmiela, ale już niedługo poczujecie się w niej bardzo dobrze i pewnie. To tutaj razem będziemy odkrywać tajemniczy świat komputerów" (Kęska 2012b: 4). Narracje kolejnych części podręcznika są budowane konsekwentnie wokół następujących kategorii: tajemniczość („tajemnicza skrzynka”), niekompetencja dziecka i jego „strach technologiczny”, stopniowy i kontrolowany akces dziecka do „świata tajemniczych skrzynek".

Pierwszą kategorię - „tajemnicę" - ilustrują następujące treści podręcznika:

Wiecie już, do czego służą komputery i gdzie są wykorzystywane. Czas stanąć oko w oko z komputerem. Dziś dowiecie się, co słychać w tajemniczych skrzynkach i po czym można poznać że komputer jest włączony (Kęska 2012a: 10).

Klawiszowe tajemnice (Kęska 2012a: 24).

Odszukaj gry do tych zajęć i sprawdź, jakie tajemnice klawiatury komputerowej udało się odkryć (Kęska 2012a: 25).

Cały rok szkolny poznawaliście tajemnice komputera (Kęska 2012a: 42).

Przez ostanie tygodnie odkrywaliście tajemnice programu graficznego (Kęska 2012b: 28) 
Drugą kategorię - „niekompetencja dziecka i strach «technologiczny»” - ilustrują następujące fragmenty:

To pracownia komputerowa. Może ta nietypowa klasa nieco was onieśmiela, ale już niedługo poczujecie się $\mathbf{w}$ niej bardzo dobrze i pewnie. To tutaj razem będziemy odkrywać tajemniczy świat komputerów (Kęska 2012a: 4).

Witajcie, Młodzi Łowcy Liter! Wiele się już nauczyliście. Umiecie rysować i zaczęliście się uczyć pisać na komputerze. A jeszcze niedawno nie wiedzieliście, jak włączyć komputer (Kęska 2012a: 26).

Trzecią kategorię - „stopniowy i kontrolowany akces dziecka do świata «tajemniczych skrzynek»" - ilustrują następujące fragmenty podręczników:

Astronauta musi się długo przygotowywać i wiele nauczyć, zanim wyruszy w kosmos. Wy już zdobyliście wiedzę potrzebną, aby rozpocząć pracę przy komputerze. Na pewno nie pomylicie komputera (jednostki centralnej) i monitora. Dziś zdobędziecie przepustkę do świata komputerów (Kęska 2012a: 12).

Wykonaj ćwiczenia do tego tematu, aby zdobyć przepustkę do niezwykłego świata komputerów w pracowni komputerowej (Kęska 2012a: 13).

Nie zapominajcie, że wakacje to czas odpoczynku - również od komputera. Do zobaczenia w krainie Internetu. To już za dwa miesiące - w trzeciej klasie (Kęska 2012b: 43).

Z pewnością warto się zastanowić nad podręcznikową (szkolną) strategią przedstawiania komputera stacjonarnego jako elementu kulturowego świata dziecka. Ciekawa jest duża liczba odniesień do „tajemnicy”, dziecięcej ignorancji i onieśmielenia w perspektywie kontaktu z urządzeniami elektronicznymi oraz etapowej organizacji tego kontaktu. Sądzimy, że obrana strategia w mniejszym stopniu odzwierciedla dziecięce doświadczenia informatyczne, a w większym tworzy podstawę dla możliwości panowania osoby dorosłej nad tymi doświadczeniami (kontekst nadzoru i władzy). Do takich stwierdzeń upoważnia nas analiza regulaminu pracowni komputerowej - dokumentu, w którym widnieją „zasady bezpiecznego korzystania z komputerów". Regulamin ten jest w niemal niezmienionej postaci (treść i ilustracje) ponawiany w kolejnych częściach podręcznika (dla pierwszej, drugiej i trzeciej klasy). W podręczniku dla klasy pierwszej widnieje zadanie do wykonania, którego celem jest utrwalenie poznanych zasad. Polega na trafnym umieszczeniu nalepek wskazujących prawidłowe i nieprawidłowe zachowanie w tabeli z kolumnami "tak" i „nie”. Regulamin pracowni komputerowej jesteśmy skłonni nazywać specyficznym programem dyscyplinarnym dotyczącym ciała, czasu, miejsca i hierarchii władzy. Wśród zasad bezpiecznego korzystania z komputera znalazły się następujące: prawidłowe ułożenie ciała (proste plecy, prawidłowa odległość od monitora), właściwa organizacja stanowiska pracy (prawidłowe oświetlenie, porządek na biurku, ikony na pulpicie komputera są również perfekcyjnie uporządkowane w dwie symetryczne kolumny), właściwy czas (nie dłużej niż godzina dziennie), prawidłowe relacje władzy (wykonywanie poleceń dorosłych). Lista niewłaściwych zachowań dotyczy również wskazanych obszarów i obejmuje: zgarbione plecy, spoglądanie na monitor 
ze zbyt bliskiej odległości, ciemny pokój i bałagan na biurku (ogryzki, nadgryziony batonik, miś, samochodzik, butelka z colą, kubek), bałagan na ekranie (wiele „pootwieranych” dokumentów), korzystanie z komputera zbyt długi czas, bez osoby dorosłej, z kanapką w ręku i kubkiem napoju.

Program dyscyplinarny zawarty w regulaminie pracowni komputerowej jest bardzo moralizatorski. Ponadto czyni z kontaktu z komputerem działanie wymagające specjalnych przygotowań i zabiegów oraz czujnego oka osoby dorosłej, nie zaś styczność, która jest spontanicznie organizowana przez bawiące lub uczące się dziecko, pozostające bez kontroli dorosłego.

Problem szkolnej władzy i nauczycielskiej kontroli uczniowskiej aktywności w związku z urządzeniami jest również przedmiotem innych uregulowań szkolnych, takich jak szkolne statuty. Zgodnie z Rozporządzeniem Ministra Edukacji Narodowej z 9 lutego 2007 roku, zmieniającym rozporządzenie w sprawie ramowych statutów publicznego przedszkola oraz publicznych szkół (Dz. U. z 2007 r. Nr 35, poz. 222) szkoły zostały zobowiązane do określenia warunków korzystania z telefonów komórkowych i innych urządzeń elektronicznych na ich terenie.

Dokonana przez nas analiza pięciu statutów trójmiejskich szkół podstawowych przekonuje, że władze szkolne dążą do zminimalizowania lub całkowitego wyeliminowania urządzeń mobilnych z własnej przestrzeni. Urządzenia te zostały bowiem zdefiniowane jako groźne i destrukcyjne (źródło zakłóceń szkolnego porządku) lub jako zabawki rozpraszające uczniowską uwagę.

Strategia 1. Minimalizowanie destrukcyjnego wptywu gadżetów elektronicznych i zabawek

Istotą tej strategii jest ograniczenie wpływu urządzeń mobilnych na życie szkolne, aczkolwiek władze szkolne zdają sobie sprawę z niemożności ich wyeliminowania ze szkolnej przestrzeni. Uznają również prawo rodziców do wyposażania dziecka w tego typu gadżety, niemniej jednak chronią siebie przed możliwością wykorzystania przez uczniów tych urządzeń jako narzędzi kontroli nad szkołą i nauczycielami:

Przykład 1:

Posiadanie i korzystanie na terenie szkoły z telefonu komórkowego przez niepełnoletniego ucznia jest możliwe w przy padku pisemnej zgody rodzica/prawnego opiekuna. Na przerwach, przed zajęciami oraz w czasie po zajęciach telefon może być używany przez uczniów wyłącznie w trybie "milczy".

Na nagrywanie dźwięku i obrazu za pomocą telefonu komórkowego i innych urządzeń elektronicznych uczeń musi mieć zgodę osoby nagrywanej lub fotografowanej. W przypadku zaginięcia telefonu lub innego urządzenia elektronicznego na terenie szkoły należy ten fakt niezwłocznie zgłosić dyrektorowi szkoły, nauczycielowi lub innemu pracownikowi szkoły.

W przypadku naruszenia przez ucznia zasad używania telefonów komórkowych i innych urządzeń elektronicznych na terenie szkoły, sprzęt zostaje zatrzymany w depozycie. Telefon komórkowy lub inne urządzenie elektroniczne mogą być odebrane przez rodzica lub prawnego opiekuna ucznia. 
Przykład 2:

Podczas zajęć edukacyjnych obowiązuje całkowity zakaz używania telefonów komórkowych. Aparaty powinny być wyłączone i schowane.

Zabrania się przynoszenia do szkoły jakiegokolwiek sprzętu grającego (na przykład MP3).

Każdego ucznia podczas pobytu w szkole obowiązuje bezwzględny zakaz fotografowania, filmowania oraz nagrywania obrazu i dźwięku innych osób bez ich wiedzy i zgody; zakaz ten dotyczy wszelkich zajęć organizowanych przez szkołę.

W przypadku złamania przez ucznia zakazu, o którym mowa w pkt. 1, 2, 3 uczeń jest zobowiązany przekazać telefon komórkowy, aparat fotograficzny, odtwarzacz MP3 lub inne urządzenie nagrywające, grające do depozytu w sekretariacie szkoły, odbiór tych urządzeń jest możliwy wyłącznie przez rodziców lub prawnych opiekunów ucznia.

\section{Strategia 2. Delegalizacja sprzętu mobilnego w szkolnej przestrzeni}

Istotą tej strategii jest próba całkowitej eliminacji urządzeń mobilnych z przestrzeni szkolnej: zakaz wnoszenia oraz korzystania ze sprzętu. Kultura szkoły i kultura mobilna podlegają tu wyraźniej separacji, brakuje tu wspólnej przestrzeni i możliwości negocjacji:

Przykład:

Szkoła jest przestrzenią wolną od urządzeń elektronicznych. Obowiązuje bezwzględny zakaz ich wnoszenia.

Każde wniesione urządzenie elektronicznie zostanie przekazane do depozytu dyrektorskiego. Odbiór jest możliwy wyłącznie przez rodziców lub opiekunów prawnych ucznia.

Jak się okazuje, rzecznik praw ucznia i rodzica otrzymuje coraz więcej skarg na nauczycieli zabierających uczniom telefony (co umożliwiają szkolne przepisy). Uważa on, że zabieranie telefonu z prywatnymi wiadomościami jest naruszeniem tajemnicy korespondencji. Jego zdaniem, gdy uczeń przeszkadza na lekcji, nauczyciel może mu obniżyć ocenę z zachowania, ale nie może skonfiskować telefonu. Poza tym czas przerwy należy traktować jako czas prywatny, w trakcie którego uczeń może wysyłać wiadomości lub rozmawiać przez telefon.

Kolejną grupą niezadowoloną z regulacji szkolnych są rodzice wyposażający dziecko w telefon po to, by kontrolować je w ciągu całego dnia i śledzić na bieżąco jego sprawy. Telefon jest ułatwieniem dla dzieci dojeżdżających do szkoły z dalszych rejonów - w każdej chwili mogą zadzwonić po rodzica lub poinformować o zmianach w planie lekcji. Również w razie wypadku na terenie szkoły dziecko ma możliwość niezwłocznego kontaktu. Wychodząc naprzeciw tym oczekiwaniom, władze szkolne zezwalają rodzicom na złożenie oświadczenia o tym, że chcą, aby dziecko korzystało w szkole z telefonu w trybie „milczy”.

Naszym zdaniem w regulacjach szkolnych mniej jednak chodzi o przeszkadzanie i brak dyscypliny wywołanej telefonami (dzwonienie, fotografowanie tablicy zamiast przepisywania z niej), a bardziej o zamianę telefonów w narzędzia kontroli - rejestrowanie przebiegu lekcji, nagrywanie nauczyciela itp. Nowe technologie mogłyby bowiem wpłynąć na zmianę relacji władzy w klasie szkolnej i „wyrównanie sił i kontroli”. 


\section{Nauczycielki wczesnej edukacji - cyfrowe imigrantki?}

W niniejszej części artykułu zwrócimy uwagę na doniesienia z badań opisujących czynniki kulturowe jako źródło edukacyjnego odrzucenia nowoczesnych technologii komunikacyjnych. Pierre Bourdieu, poddając analizie fenomen męskiej dominacji we współczesnych społeczeństwach, podkreślał, że mimo niewątpliwych zmian, które wpłynęły na umocnienie pozycji kobiet, w dalszym ciągu utrzymuje się kilka kulturowych „niezmienników” odtwarzających symboliczną granicę świata męskiego i kobiecego oraz ich hierarchiczny układ. Jednym z nich jest kulturowo skonstruowana „niesprawność” techniczna kobiet wyrażająca się w postaci społecznego przyzwolenia (a niekiedy wręcz oczekiwania takich oznak i ukrywania posiadanych kompetencji) dla publicznych manifestacji niekompetencji w zakresie technicznym przez kobiety, demonstrowania przez nie bezradności i oczekiwania wsparcia ze strony mężczyzn, zyskujących tym samym status ekspertów, niezależnie od ich faktycznej eksperckości w tej materii (Bourdieu 2004: 43). Przedstawione w poprzedniej części artykułu analizy rodzinnego kontekstu kultury cyfrowej nie potwierdzają jednak diagnozy Bourdieu. Można by się nawet pokusić o optymistyczny wniosek, że „mobilna rewolucja” okazała się zaskakująco inkluzywna w aspekcie gender: wyniki badań M(obile) Mama wskazują, że to głównie kobiety udostępniają dzieciom własne urządzenia mobilne, a zatem to one otwierają dzieci na kulturę cyfrową.

Jednak wyniki badań, omawiane w dalszej części artykułu, nakazują zachowanie pewnej ostrożności. Udało się nam odnaleźć analizy wskazujące na istnienie „wysp edukacyjnego oporu” wobec kultury cyfrowej: oporu o wyraźnie genderowym charakterze.

Paolo Ferri i Susanna Mantovani, analizując potencjały edukacyjne mobilnych technologii komunikacyjnych, zwrócili uwagę na społeczno-kulturową konstrukcję płci (Ferri, Mantovani 2006: 63). Zdaniem autorów wrogość wobec nowoczesnych urządzeń mobilnych jest bowiem nie tylko wpisana w kulturę włoskiej szkoły, ale przede wszystkim w genderową konstrukcję zawodu nauczycielskiego. Włoskie nauczycielki wczesnej edukacji nie są, jak się okazuje, przygotowywane do tego, by kultura cyfrowa budowała w jakiejś mierze ich zawodowy warsztat. Przeciwnie - profil ich przygotowania zawodowego jest kulturowo konserwatywny, dlatego na uniwersytetach zyskują przyzwolenie na umniejszanie jej wartości lub nawet demonizowanie (nagminne pomijanie kultury cyfrowej w kształceniu nauczycielskim sprawia, że ten kontekst socjalizacji dziecięcej staje się przedmiotem demagogicznej krytyki, mnożenia obaw i uprzedzeń). Włoskie nauczycielki edukacji wczesnoszkolnej są natomiast - jak przekonują Ferri i Mantovani - mocno przywiązane do dyskursu dziecięcej natury, która - aby prawidłowo się rozwijać - powinna pozostać "nietknięta” przez nowoczesną technologię (Ferri, Mantovani 2006: 66). Tym samym nauczycielki przypisują sobie zawodowy monopol na definiowanie, czym jest dziecięca natura, określając, w jakich warunkach społecznych, kulturowych i szkolnych ma szansę najpełniejszego rozwoju. Przywiązanie do romantycznej koncepcji natury dziecka i prawidłowo zorganizowanego (znormalizowanego) środowiska uczenia się powoduje, że włoskie nauczycielki tworzą jedną z najbardziej konserwatywnych grup broniących „czystości” szkoły i „czystości” (nietechnologiczności) dzieciństwa, często 
wbrew samym dzieciom i ich rodzicom. Ich opór przed wykorzystywaniem mobilnych urządzeń w edukacji zawarty jest w stwierdzeniu: „[...] nowe technologie komunikacyjne zamienią dzieci w maszyny" (Ferri, Mantovani 2006: 68). Koncepcje „naturalności”, „naturalnego środowiska”, „prawidłowego rozwoju” i nauczycielskiego profesjonalizmu zdefiniowanego jako sprawowanie pieczy (kontroli) nad tym, co „naturalne”, tworzą wyjątkowo mocną barierę zabezpieczającą włoską edukację przez wpływami „nienaturalnej” kultury cyfrowej. Jesteśmy przekonani, że praktyka polskiej wczesnoszkolnej edukacji nie jest bardzo odległa od włoskiej.

Z badań Ferri i Mantovani nie dowiadujemy się, czy wspomniana grupa nauczycielek wykluczyła urządzenia z ekranami dotykowymi także z własnego pozazawodowego życia. Przypuszczamy jednak, że ich „naturalizm” nie wiąże się z określonym typem osobistych przekonań i postaw (wolność od technologii, ekologia głęboka praktykowana we własnym, prywatnym życiu itp.), co raczej ze specyficzną, ugruntowaną zawodowo formą władzy nad dzieckiem i środowiskiem jego rozwoju. Zatem nie sądzimy, by nauczycielki wczesnej edukacji tworzyły - ze względu na niekompetencję i brak umiejętności poruszania się w świecie mobilnych urządzeń - bardzo specyficzną grupę cyfrowych imigrantek wrogo ustosunkowanych wobec dzieci (reprezentujących pokolenie cyfrowych tubylców). Jednak kultura szkoły i koncepcja zawodu w taki właśnie sposób je pozycjonuje.

\section{Zakończenie}

W Polsce popularność urządzeń z ekranem dotykowym w najmłodszej dziecięcej populacji (i nie tylko) dynamicznie wzrasta. Jak przekonują relacje dziennikarskie, tegoroczną "jedynką" na liście pierwszokomunijnych prezentów są smartfony, tablety, a zwłaszcza iPady. Również lektura forów internetowych (na przykład www.mjakmama24.pl) przekonuje, że rodzice najmłodszych dzieci (trzylatków) dyskutują o sensowności zakupu tabletu dla dziecka (M jak mama 2013). Interesujące nas urządzenia stają się integralną częścią dziecięcego świata ${ }^{8}$, nową przestrzenią dzieciństwa i nowym środowiskiem uczenia się w kontakcie z aktywnymi przedmiotami oraz elementem konstrukcji dziecięcej tożsamości. Interesujące w tej perspektywie będzie obserwowanie reakcji szkoły na inwazję ekranów dotykowych. Dotychczasowe sposoby „radzenia sobie” polskiej szkoły z mobilną technologią wskazują raczej na obecność konfliktu kulturowego niż na wykorzystanie edukacyjnego potencjału nowych technologii.

Jesteśmy przekonani, że wiedza o dziecięcych sposobach partycypacji w kulturze cyfrowej oraz o rodzinnych strategiach włączania aktywnych przedmiotów w sferę socjalizacji, wychowania i uczenia się doprowadzi do rozpoznania i uznania edukacyjnego potencjału mobilnych technologii we wczesnej edukacji (i edukacji przedszkolnej), pobudzi badania w tym zakresie m-learningu oraz zminimalizuje dyskurs „nowych technologii komunikacyjnych jako bezwzględnego zagrożenia rozwojowego dziecka” oraz dyskurs „tabletu uspakajającego” obecnego w kulturze popularnej.

\footnotetext{
${ }^{8}$ Mamy oczywiście świadomość istnienia podziału cyfrowego, który dotyczy także dziecięcej populacji.
} 


\section{Literatura:}

Ally M., 2009, Mobile Learning. Transforming the Delivery of Education and Training, Athabasca: Athabasca University Press.

Bourdieu P., 2004, Męska dominacja, Warszawa: Oficyna Naukowa.

Brandon J., 2011, Is the iPad a 'Miracle Device' for Autism?, http://www.foxnews.com/ tech/2011/03/09/can-apple-ipad-cure-autism/\#ixzz2SJkJGJqC [dostęp: 1.03.2013].

Caron A.H., Caronia L., 2001, Active Users and Active Object. The Mutual Construction of Families and Communication Technologies, "Convergence. The Journal of Research into New Media Technologies" Vol. 7, No. 3.

Caron A.H., Caronia L., 2007, Moving Cultures. Mobile Communication in Everyday Life, Montreal: McGill-Queen's University Press.

Caronia L., 2005, Mobile Culture: An Ethnography of Cellular Phone Use in Teenagers' Everyday Life, "Convergence. The Journal of Research into Media Technologies" Vol. 11, No. 3.

Castells M. et al., 2004, The Mobile Communication Society, California: University of Southern California.

Ferri P., Mantovani S. (a cura di), 2006, Bambini e computer. Alla scoperta delle nuove tecnologie a scuola e in famiglia, Milano: Razzoli Etas.

Is the iPad bad for children? Experts debate merits of kids spending too much time on tablets, iPods, 2012, http://www.nydailynews.com/life-style/health/ipad-bad-children-experts-debate-merits-kids-spending-time-tablets-ipods-article-1.1054449\# ixzz2SFzF47k0 [dostęp: 1.03.2013].

Izdebska J., 2007, Dziecko w świecie mediów elektronicznych. Teorie, badania, edukacja medialna, Białystok: Wydawnictwo Uniwersyteckie Trans Humana.

Kęska M., 2012a, Zajęcia komputerowe. 1: Podręcznik z ćwiczeniami, Warszawa: Wydawnictwo Nowa Era.

Kęska M., 2012b, Zajęcia komputerowe. 2: Podręcznik z ćwiczeniami, Warszawa: Wydawnictwo Nowa Era.

Latour B., 2010, Przedmioty także posiadaja sprawczość [w:] Teoria wiedzy o przeszłości na tle wspótczesnej humanistyki. Antologia, red. E. Domańska, Poznań: Wydawnictwo Poznańskie.

M jak mama, 2013, http://www.mjakmama24.pl/rodzice/bezpieczenstwo/internet/czytablet-dla-dziecka-nie-przesada,225_5246.html [dostęp: 1.03.2013].

Mead M., 1978, Kultura i tożsamość: studium dystansu międzypokoleniowego, wstęp W. Adamski, tłum. J. Hołówka, Warszawa: PWN.

Olsen B., 2010, Kultura materialna po tekście. Przywracanie obecności rzeczom [w:] Teoria wiedzy o przeszłości na tle wspótczesnej humanistyki...

Orton-Johnson K., Prior N. (eds.), 2013, Digital Sociology: Critical Perspectives, New York: Palgrave Macmillan.

Pope G., Global Apps Study, 2012, http://www.kidsindustries.com/blog/2012/10/global-apps-study [dostęp: 1.03.2013].

Prensky M., 2001a, Digital Natives, Digital Immigrants, „On the Horizon” No. 5.

Prensky M., 2001b, Digital Natives, Digital Immigrants, Part II, "On the Horizon” No. 6.

Rozporządzenie Ministra Edukacji Narodowej z dnia 23 grudnia 2008 r. w sprawie podstawy programowej wychowania przedszkolnego oraz kształcenia ogólnego w poszczególnych typach szkół (Dz. U. z 2009 r. Nr 4, poz. 17).

Seales R., Harding E., 2013, Four-year-old girl is Britain's youngest iPad ADDICT: Schocking rise in children hooked on using smartphones and tablets, http://www.dailymail.co.uk/news/article-2312429/Four-year-old-girl-Britains-youngest-iPad-ADDICT-Shocking-rise-children-hooked-using-smartphones-tablets.html [dostęp: 1.03.2013].

Siuda P., Stunża G.D. (red.), 2012, Dzieci Sieci: kompetencje komunikacyjne najmłodszych: raport z badań, Gdańsk: Instytut Kultury Miejskiej. 
Tomaszewska H., 2012, Młodzież, rówieśnicy i nowe media. Społeczne funkcje technologii informacyjnych w życiu nastolatków, Warszawa: Wydawnictwo Akademickie Żak.

Urist J., 2013, iPotty: Brilliant, or worst idea ever? Experts weigh in on new potty training device, http://www.today.com/moms/ipotty-brilliant-or-worst-idea-ever-experts-weighnew-potty-1B7987623 [dostęp: 1.03.2013].

\section{Summary}

\section{Children within Digital Culture}

The main aim of the presented article is to provide knowledge on educational potential of digital culture, m-learning infrastructure and its educational content within the field of early education. It examines the patterns of children's learning, cognition and action within family and school learning and socialization and the readiness of early education teachers for the elements of digital teaching in their professional domain. These studies are relevant to the pedagogy of early education, innovative pedagogy, digital teaching and sociology of education in Poland.

\section{Keywords}

children, school, mobile culture, family, digital socialization

\section{Słowa kluczowe}

dzieci, szkoła, mobilna kultura, rodzina, cyfrowa socjalizacja 